\title{
Heterospecific and conspecific associations of trees in lowland tropical forest of New Guinea
}

\author{
AGUSTINUS MURDJOKO ${ }^{1,2, \vartheta}$, MARTHEN MATHIAS JITMAU ${ }^{2}$, DONY ARISTONE DJITMAU ${ }^{1}$, \\ RIMA HERLINA SETIAWATI SIBURIAN ${ }^{1}$, ANTONI UNGIRWALU ${ }^{1}$, ALFREDO OTTOW WANMA ${ }^{1}$, \\ ZULFIKAR MARDIYADI ${ }^{1}$, ALEXANDER RUMATORA ${ }^{1}$, WOLFRAM YAHYA MOFU ${ }^{1}$, \\ ANTON SILAS SINERI ${ }^{1}$, SEPUS MARTEN FATEM ${ }^{1}$, DESCARLO WORABAI ${ }^{1}$, NUNANG LAMAEK MAY ${ }^{1}$, \\ MAX JONDUDAGO TOKEDE ${ }^{1}$, HERMAN WARMETAN ${ }^{1}$, CHARLY BRAVO WANGGAI, \\ JIMMY FRANS WANMA ${ }^{1}$, ELIESER VIKTOR SIRAMI ${ }^{1,2}$, JOHANA BETY PAEMBONAN ${ }^{3}$, ERNI UNENOR $^{4}$, \\ RELAWAN KUSWANDI ${ }^{5}$, KRISMA LEKITOO ${ }^{5}$, LISNA KHAYATI ${ }^{5}$, NITHANEL MIKAEL HENDRIK BENU ${ }^{5}$, \\ JUNUS TAMBING ${ }^{5}$, ANDI SASTRA BENNY SARAGIH ${ }^{6}$ \\ ${ }^{1}$ Faculty of Forestry, Universitas Papua. Jl. Gunung Salju, Amban, Manokwari 98314, West Papua, Indonesia. \\ "email: agustinus.murdjoko.papua@gmail.com \\ ${ }^{2}$ Research Center of Biodiversity, Universitas Papua. Jl. Gunung Salju, Amban, Manokwari 98314, West Papua, Indonesia \\ ${ }^{3}$ Environmental Services, Pegunungan Bintang District. Oksibil, Pegunungan Bintang 99573, Papua Province, Indonesia \\ ${ }^{4}$ Forestry Service, Papua Province. J1. Tanjung Ria Base G 99771, Tanjung Ria, Jayapura City 99117, Papua, Indonesia \\ ${ }^{5}$ Forestry Research and Development Agency of Manokwari. Jl. Inamberi-Susweni, Manokwari 98301, West Papua, Indonesia \\ ${ }^{6}$ Perkumpulan Mnukwar. Jl. Manunggal Besar, Amban, Manokwari 98314, West Papua, Indonesia
}

Manuscript received: 22 August 2020. Revision accepted: 29 August 2020.

\begin{abstract}
Murdjoko A, Jitmau MM, Djitmau DA, Siburian RHS, Ungirwalu A, Wanma AO, Mardiyadi Z, Rumatora A, Mofu WY, Sineri AS, Fatem SM, Worabai D, May NL, Tokede MJ, Warmetan H, Wanggai CB, Wanma JF, Sirami EV, Paembonan JB, Unenor E, Kuswandi R, Lekitoo K, Khayati L, Benu NMH, Tambing J, Saragih ASB. 2020. Heterospecific and conspecific associations of trees in lowland tropical forest of New Guinea. Biodiversitas 21: 4405-4418. The vegetation in the tropical rainforest of New Guinea consists of a large number of species that interact with each other within and among species. While several studies have attempted to reveal the diversity of flora of New Guinea, little is known about plant communities that develop associations. This study aimed to investigate the associations of tree species in lowland tropical forest in New Guinea. The associations depicted in this study were in the form of conspecific associations (among small and large individuals within same species) and heterospecific (among individuals of different species and divided into under and upper story). We established 48 rectangular plots created in Murkim and Teiraplu as part of Pegunungan Bintang District, Papua Province. Canonical correspondence analysis (CCA) was used to analyze heterospecific and conspecific associations. The results showed that the understory and upper story vegetation had different patterns of heterospecific association. The understory configured three heterospecific associations, consisting of 5, 13, and 90 species, while the upper story formed four heterospecific associations with 4, 8, 11, and 63 species. The analysis of conspecific associations showed of 149 tree species recorded in the study sites, only 66 species that had both small and large individuals, displaying the pattern of conspecific association. Among them, 41 species had positive associations while 25 species had negative associations. Our findings enrich the knowledge in theoretical ecology of tropical forests, especially in New Guinea.
\end{abstract}

Keywords: Canonical correspondence analysis, CCA, Papuasia, tree community, tropical rainforest, vegan package

\section{INTRODUCTION}

Tropical rainforest is a complex ecosystem with many interactions between abiotic and biotic factors, particularly among vegetation (Vitousek 1984; Thomas and Baltzer 2002; Hunter et al. 2015). This complexity results in the vegetation that consists of many life forms from vertical and horizontal compositions that interact with each other to obtain sunlight, soil nutrients, and water, and to adapt with microclimatic conditions (Slik et al. 2015, 2018; Murdjoko et al. 2016a). The interactions among vegetation have occurred over a long period due to successional process (Fernández-Lugo et al. 2015). Where the vegetation shares the same ecological condition, the morphological and physiological characters become the driving factors of behavior in the natural tropical rainforest (Gustafsson et al. 2016; Johnson et al. 2017).
The interactions among vegetation elements in the tropical rainforest in some cases represent symbiosis and inter and intra-species relationships (Legendre and Fortin 1989; Magrach et al. 2014). These interactions can be in the form of competition and association. In old tropical rainforest, the interaction occurs intensively due to the absorption of light and water, where both are the primary growth factors (Yamamoto 2000; Montgomery and Chazdon 2001). In secondary forest, canopy gap is very open, leading to more light penetrating the forest floor (Itoh et al. 1997; Angelini et al. 2015; Murdjoko et al. 2017).

The association in vegetation communities can be in the form of conspecific or heterospecific and the form of association determines the pattern of the spatial distribution of forest ecosystems either. Conspecific association is the interaction of individuals of similar species while heterospecific occurs among different species of vegetation 
(Zhu et al. 2015; Wang et al. 2018). Conspecific and heterospecific associations occur during the successional process of the tropical rainforest (Farneda et al. 2018). Some studies explained that the association, either the conspecific or the heterospecific could be in a positive or negative pattern (Castilla et al. 2016).

Vegetation is distributed geographically with the diversity and pattern of plant communities that adapt to particular ecological niche (Brummitt 2001; Pan et al. 2013). Phytogeographic regions, including mainland New Guinea, have been studied for centuries. The vegetation in New Guinea spreads from coastal to high land areas, containing various types of ecosystems (Cámara-Leret and Dennehy 2019). As the result, New Guinea contains the highest diversity of flora, such as trees, climbers, shrubs, ferns, rattan, etc. (Murdjoko et al. 2016a) in which about $60 \%$ of the species are endemic (Cámara-Leret et al. 2020). For example, a forest area in New Guinea consists of a high diversity of tree species with more than 70 species per hectare that could be found (Robiansyah 2018; Fatem et al. 2020). While recently more and more studies have attempted to reveal the diversity of flora of New Guinea, little is known about plant communities that develop associations among them.

This study aimed to investigate the association of tree species in the lowland tropical forest in New Guinea. The associations depicted in this study were in the form of conspecific associations (among small and large individuals within same species) and heterospecific (among individuals of different species and divided into under and upper story). We hypothesized that the small and large tree species have heterospecific associations within the natural tropical rain forest. This kind of study is important to provide specific contribution of ecological research in the tropical rainforest of Southeast Asia, more specifically the New Guinea region (Brummitt 2001).

\section{MATERIALS AND METHODS}

\section{Study period and area}

This study was conducted in the northern part of Pegunungan Bintang District (Ind.: kabupaten), Papua Province, Indonesia (Figure 1). The study sites were located at Murkim ( $4^{\circ} 0^{\prime} 0.53 " \mathrm{~S}$ and $\left.140^{\circ} 49^{\prime} 17.24 " \mathrm{E}\right)$ and Teiraplu ( $3^{\circ} 59^{\prime} 13.46 " \mathrm{~S}$ and $\left.140^{\circ} 26^{\prime} 0.06 " \mathrm{E}\right)$ at an altitude of $155 \mathrm{~m}$ and $233 \mathrm{~m}$ above sea level ( $\mathrm{m}$ asl), respectively. The ecosystem type of the two study sites are categorized as lowland areas where the southern part is bordered with the mountain range and the northern part is bordered with hills while the western and eastern parts are lowlands. Broadleaves and mixed forests are the dominant vegetation in this area, while the soil is grouped as Ultisols and Inceptisol. The climatic conditions are considered to be very humid with average temperature of $25^{\circ} \mathrm{C}$ for annual, $20.6^{\circ} \mathrm{C}$ for daily, and $16.3^{\circ} \mathrm{C}$ for minimum, and with monthly and annual average rainfall of $448.75 \mathrm{~mm}$ and $5385 \mathrm{~mm}$, respectively (Kartikasari et al. 2012).

\section{Sampling and data collection}

Data were collected using sampling plot method with size of each plot $20 \mathrm{~m} \times 20 \mathrm{~m}$. In total, there were 48 rectangular plots established in which 24 plots were in Teiraplu and 24 plots were in Murkim. In both locations, the plots were placed to north directions at a distance of $100 \mathrm{~m}$ away from each other. In the $20 \mathrm{~m} \times 20 \mathrm{~m}$ plot (A) we recorded and measured old trees with a diameter of more than $20 \mathrm{~cm}$, and within this plot we established three nested sub-plots with size $10 \mathrm{~m} \mathrm{x} 10 \mathrm{~m}$ (B) to record tree with diameter between $10 \mathrm{~cm}$ and $20 \mathrm{~cm}$, size $5 \mathrm{~m}$ x $5 \mathrm{~m}$ (C) to record trees taller than $1.5 \mathrm{~m}$, and size $2 \mathrm{~m} \mathrm{x} 2 \mathrm{~m}$ (D) to record the species shorter than $1.5 \mathrm{~m}$. The vegetation in plots A and B were classified as upper story and that in plots $\mathrm{C}$ and $\mathrm{D}$ were categorized as understory. For the understory vegetation, we recorded data of taxonomic names of every species and number of individuals, and while for the upper story vegetation we recorded data of taxonomic names of every species, number of individuals, and diameter $(\mathrm{cm})$.

For identification, we collected the specimens of the plant and sent it to the Herbarium Papuaense of Balai Penelitian dan Pengembangan Lingkungan Hidup dan Kehutanan (BP2LHK) Manokwari and Herbarium Manokwariense (MAN) Pusat Penelitian Keanekaragaman Hayati Universitas Papua (PPKH-UNIPA), Manokwari. The species name was updated according to The Plant List (TPL) at the website of http://www.theplantlist.org/.

\section{Statistical analysis}

The heterospecific and conspecific associations were analyzed using the canonical correspondence analysis (CCA) (Ter Braak 1986; Caceres and Legendre 2009), and the chi-square test $\left(\chi^{2}\right)$ was implemented to validate the model of CCA (Fatem et al. 2020). Furthermore, this association used the number of each individual (density) as a value in which the columns were the species and the rows were the 48 plots. The conspecific association correlated the under and upper story as small and large individuals. The columns represented the species, while the 48 plots under and upper story represented the rows. The species that did not have under and upper stories were otherwise excluded. The result of CCA displayed species in the graph with the position in the two axes. To investigate the conspecific association whether it was positive or negative, the Euclidean distance between each species as well as the under and upper stories were conducted (Murdjoko et al. 2016b, 2017). If the result of Euclidean distance of species is below the average, then the conspecific association is said to be positive, and vice versa. The vegan package in $\mathrm{R}$ version 3.5.3 was used to calculate the statistical analysis (Oksanen et al. 2019). 

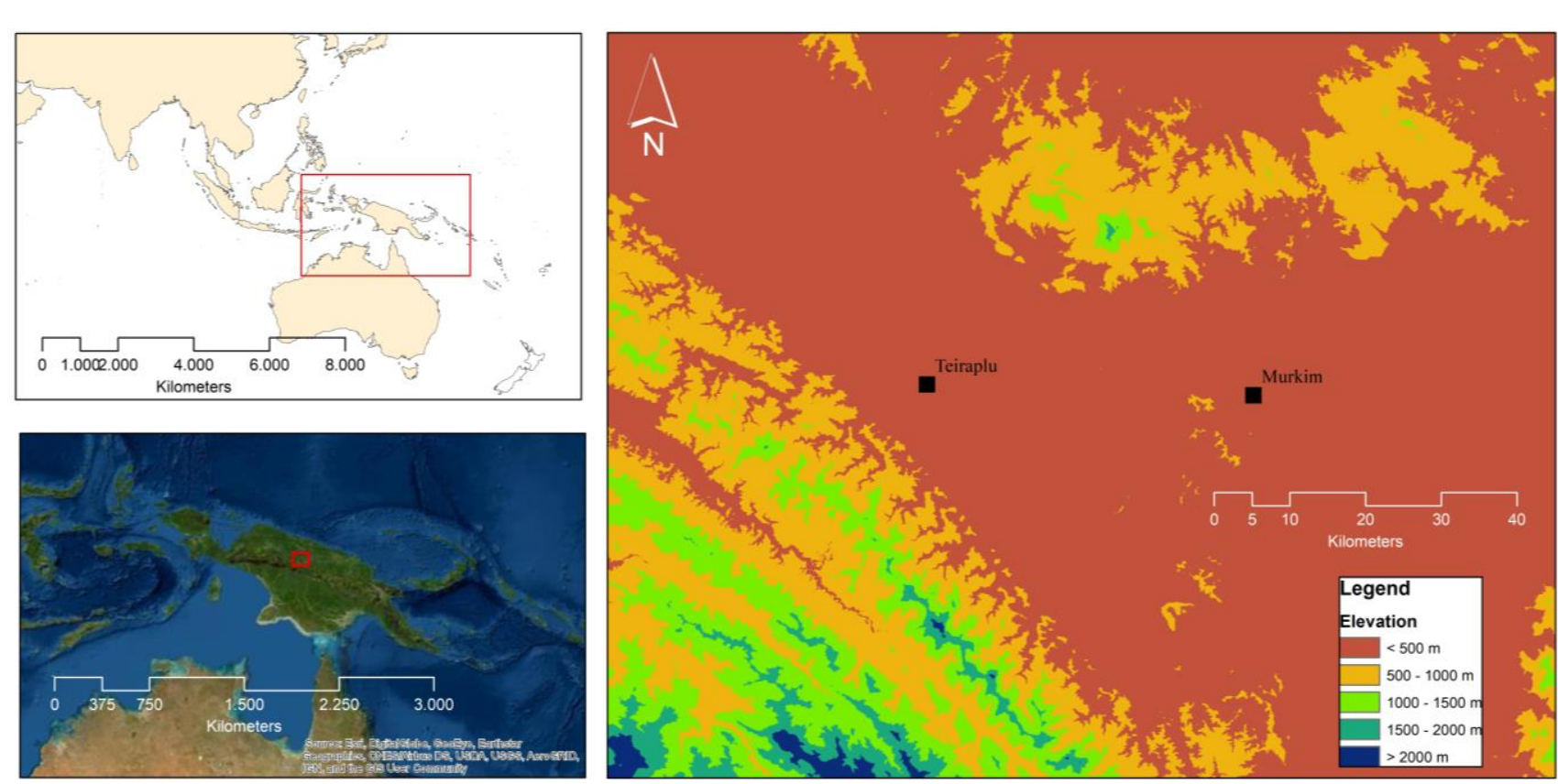

Figure 1. Map of the study sites in Teiraplu and Murkim, Pegunungan Bintang, Papua, Indonesia

\section{RESULTS AND DISCUSSION}

\section{Heterospecific associations}

The heterospecific association was grouped into two: understory and upper story, based on the structure of trees in tropical forests. As such, the analyses of multivariate statistics for the understory and upper story were separated since the natural tropical rainforest is complex with the vegetation structures forming the ecosystem. The structure was also simplified by distinguishing them into two main parts.

From the CCA result, the understory and upper story showed different patterns of heterospecific association. The understory configured three groups of communities based on species as the structure of the associations. The three groups are shown in Figure 2.

The results showed that 108 species of trees formed the association in natural tropical forests, and was valid statistically as $\chi^{2}=10.686$, df $=2461$, p-value $=1$. The species of understory showed heterospecific associations as tree groups where the first consisted of 90 species (blue boxes), the second contained 13 (green boxes), and the third comprised of 5 species (red boxes) (Figure 2). The name of the species in the boxes in Figure 2 was abbreviated and the complete name can be seen in Table S1.

The CCA result showed that the upper story vegetation community had a pattern of association with a valid result of $\chi^{2}=11.344, \mathrm{df}=1955, \mathrm{p}$-value $=1$. The upper story consisted of 86 species which formed four heterospecific associations, consisting of the first group (63 species) in the grey boxes, second group (11 species) in the red boxes, third group ( 8 species) in the purple boxes, and fourth group (4 species) in the blues boxes (Figure 3$)$. The complete name of species presented in Figure 3 can be seen in Table S2.

The association pattern of the understory and upper story differed from one another even though they grew in the same natural forest. The difference in association has likely resulted from the variation of the vertical structure of the tropical forest. The upper story vegetation has reached the emergent layers of forest canopy, allowing species to benefit by getting more sunlight (Murdjoko et al. 2016a, 2017; Fatem et al. 2020). The formation of understory was caused by competition due to it is below the canopy layers with low solar radiation (Rüger et al. 2011; Laurans et al. 2014; Angelini et al. 2015).

For centuries, the formation of tropical forests has been a sequential process in which large numbers of species compete dynamically each other (Brown et al. 1990; Wright and Muller-Landau 2006; Liu and Slik 2014; Almeida et al. 2019). The heterospecific association can be related to the fact that trees interact with each other to form symbiosis with other life forms, such as liana, fern, herb, epiphyte, etc. (Johnson et al. 2017; Cirimwami et al. 2019; Steege et al. 2019). The primary factor influencing the pattern of tree communities of understory and upper story during tropical forest succession was probably caused by the abiotic factors, especially to gain nutrients, water, and sunlight as materials to support metabolisms, especially photosynthesis. Nonetheless, many studies showed that the morphological and physiological characters have also affected different responses of species to grow and develop (Goodale et al. 2012; Gustafsson et al. 2016). For example, the nature of shade tolerance species may be a factor that allows small tree species to survive the competition and obtain limited sunlight below the canopy layers (Givnish 1999; Montesinos-Navarro et al. 2018). Therefore, it is 
crucial to study the shade-tolerant characters of a species in the rainforest in order to explain forest dynamics in more detail. This study is unable to reveal such characters concerning the light competition because that is beyond the scope is this study.

\section{Conspecific associations}

The analysis of conspecific associations was conducted using 149 species that grew in the study sites, but only 66 species that had small and large individuals as understory and upper story. The result of CCA showed statistically valid result as $\chi^{2}=5.8784$, df $=2904$, $p$-value $=1$ (Figure 4). In addition, it displayed the pattern of conspecific association as 41 species had positive association while 25 species had negative association. In the positive association, the small and large individuals of the 41 species were distributed closely in the same area, representing the tendency of mature trees to reproduce and germinate. Conversely, in the negative association, the small individuals of the 25 species grew mainly far from the large ones that represent the matured trees. The full list of the taxonomic name of the species in Figure 4 is presented in Table S3, and the conspecific association can be used to analyze their density dependence since the tropical forest is the place for the high diversity of trees.

Of 149 species, 83 species did not have either small or large individuals, suggesting that the species experienced poor regeneration. Some large individuals act as putative parent trees, even though they have failed to establish seedlings due to many factors (Seidler and Plotkin 2006; Rahman and Tsukamoto 2015). One possible factor is caused by the competition of seedlings with other plants on the forest floor, on which many life forms are found. Another rationale is that the seeds and seedlings are eaten by herbivores (Swaine et al. 1987; Houter and Pons 2014).
Many studies have reported that herbivores are found in tropical rainforest since the forest provides a lot of food, for example, during germination, the dicotyledonous tree plants develop shoot from the plumule of the germinating seed (Houter and Pons 2014; Sawada et al. 2015).

The distribution of individual trees in tropical forests is influenced by the ability to interact with other species. This pattern of conspecific association should be studied frequently to figure out the method of regeneration and distribution of species. Forest floor encompasses many species with different life forms as a strategy to survive and grow during the competition (Dezzotti et al. 2019). Many lianas and climbers grow fast to occupy the forest canopy and space available for sunlight. These plants suppress a certain seedling establishment (Carreño-Rocabado et al. 2012). The competition to gain sunlight, nutrition, and water is presumed as the limiting factor suffered by some species since they cannot survive below putative parent trees.

Seed dispersal can be the driving force behind the spatial distribution of plants in tropical forests. Moreover, the morphological and anatomical characters of seeds and fruits also influence species regeneration and distribution. For example, small and winged seeds of tree species can spread out by falling around and away from the parent trees (Sebbenn et al. 2008; Lü and Tang 2010). However, factors such as competition, herbivory, and allelopathy have led to a clear and negative association in natural tropical forests (Padmanaba and Corlett 2014; Menezes et al. 2019). In contrast, large seeds mostly fall around the parent trees and since they survived germination, they can grow as positive conspecific associations. Therefore, the conspecific association pattern should be studied to know the natural regeneration of certain species in tropical rainforest.

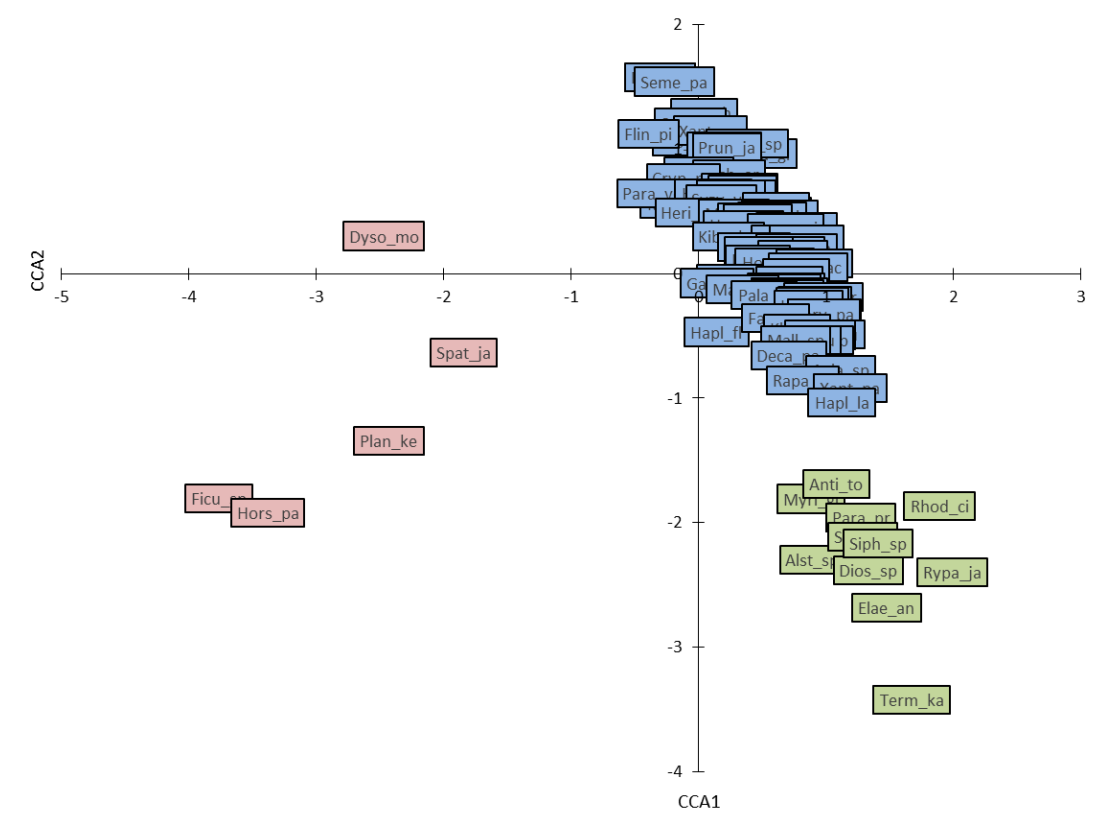

Figure 2. The result of Canonical Correspondence Analysis (CCA) to analyze the heterospecific associations for understory. 


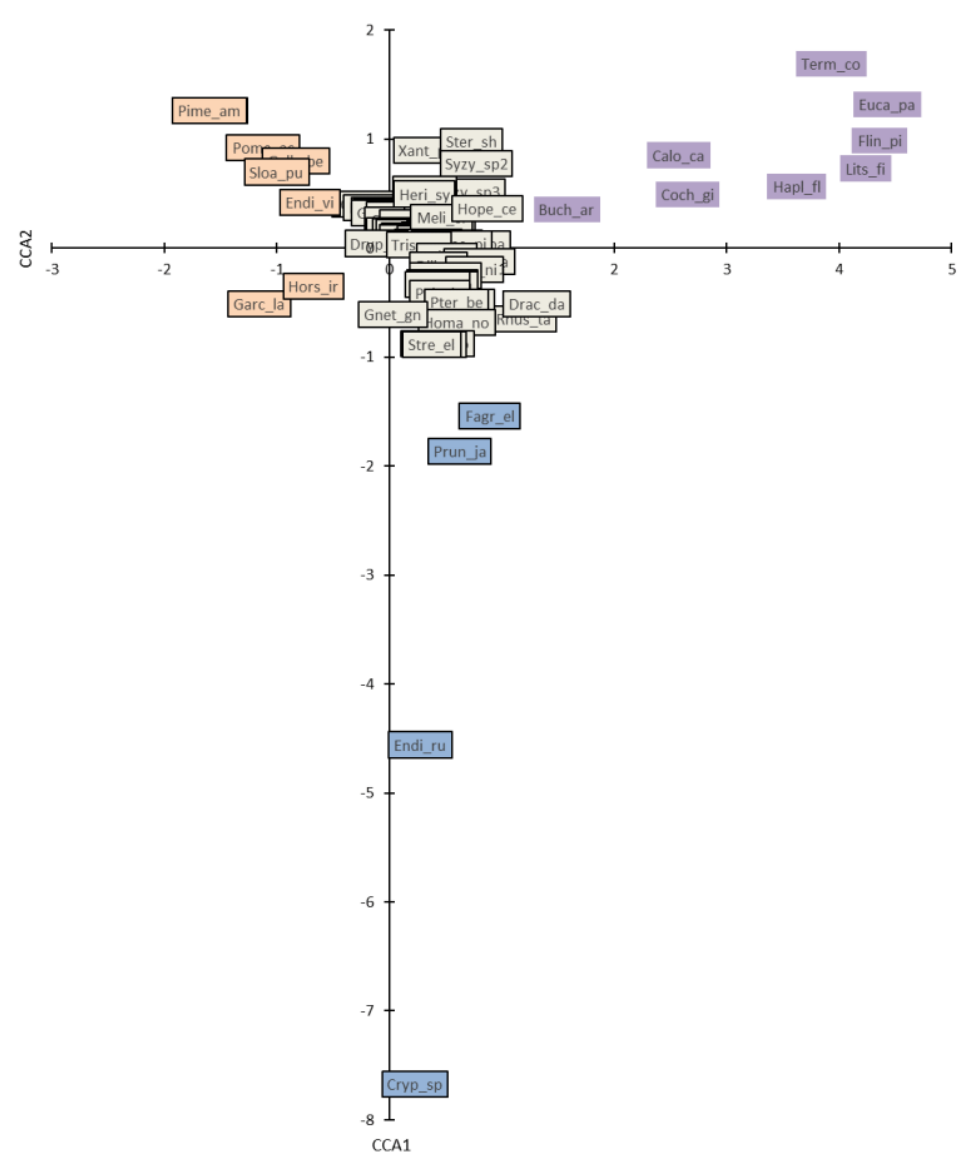

Figure 3. The result of Canonical Correspondence Analysis (CCA) to analyze the heterospecific associations for the upper story

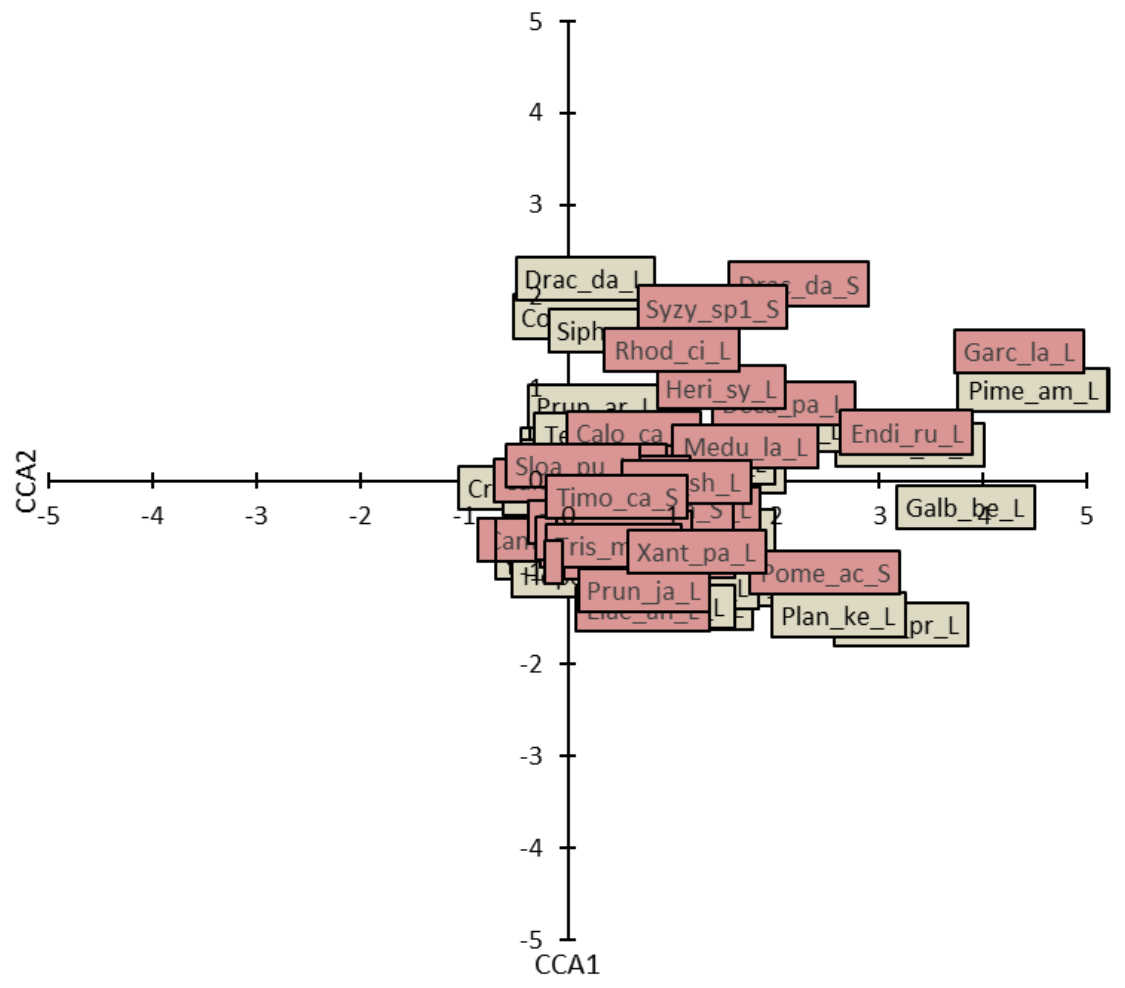

Figure 4. The result of Canonical Correspondence Analysis (CCA) to analyze conspecific associations between the small and the large individuals of the same species 


\section{The implication of associations to ecological knowledge for sustainable management of primary forest}

The study of conspecific and heterospecific associations in tropical rainforest is extremely important to determine the spatial distribution pattern, especially the conspecific association. In addition, a model of natural regeneration of tree species can be described, and the result can indicate the pattern of recruitment in the population dynamics of tree species (Goodale et al. 2012; Piotto et al. 2019). Tropical rainforest is primarily dominated by flowering plants with their reproduction season is in annual period (Baker et al. 1998; Pan et al. 2013; Cámara-Leret et al. 2020). Furthermore, a suitable area for certain species to grow has resembled in the conspecific association since the study correlates small individuals with the large ones within the same species. The pattern of conspecific association can also be used to observe natural regeneration. For example, the most appropriate area to plant tree species in-situ conservation programs can be decided when artificial regeneration is necessary (Armstrong et al. 2011; Vergara-Rodrígue et al. 2017). The heterospecific association describes the pattern of growth in tropical rainforest since the forest includes the great diversity of tree species. The forest took several decades to develop, and this present study has been able to analyze the pattern of tree species association. Ecological studies on the theme of species association in tropical rainforest need to be replicated in other contexts of region, ecosystem type and forest conditions as tropical forest is very complex as made up of different life forms that interact and create vertical and horizontal structures in the climax phase of the successional process (Chazdon 2003; Brokaw and Scheiner 2012).

\section{ACKNOWLEDGEMENTS}

The authors thank Pegunungan Bintang District, Papua, Indonesia for the financial support, and also anonymous reviewers for improving this manuscript.

\section{REFERENCES}

Almeid DRA, Stark SC, Schietti J, Camargo JLC, Amazonas NT, Gorgens EB, Rosa DM, Smith MN, Valbuena R, Saleska S, Andrade A, Mesquita R, Laurance SG, Laurance WF, Lovejoy TE, Broadbent EN, Shimabukuro YE, Parker GG, Lefsky M, Silva CA, Brancalion PHS. 2019. Persistent effects of fragmentation on tropical rainforest canopy structure after 20 Yr of Isolation. Ecol Appl 29 (6): 1221 1235 .

Angelini, Alice, Corona P, Chianucci F, Portoghesi L. 2015. Structural attributes of stand overstory and light under the canopy. Ann Silvicultural Res 39 (1): 23-31.

Armstrong AH. Shugart HH, Fatoyinbo TE. 2011. Characterization of community composition and forest structure in a Madagascar lowland rainforest. Trop Conserv Sci 4 (4): 428-444.

Baker WJ, Coode MJE, Dransfield J, Dransfield S, Harley MM, Hoffmann P, Johns RJ. 1998. Patterns of distribution of Malesian vascular plants. Biogeogr Geol Evol SE Asia 243-258.

Brokaw NVL, Scheiner SM. 2012. Species composition in gaps and structure of a tropical forest. Ecology 70 (3): 538-541.
Brown S, Lugo AE, Brown S, Hall M, Gregory W, Lugo AE. 1990. Tropical secondary forests. J Trop Ecol 6 (1): 1-32.

Brummitt RK. 2001. World Geographical Scheme for Recording Plant Distributions. International Working Group on Taxonomic Databases For Plant Sciences (TDWG). Hunt Institute for Botanical Documentation, Carnegie Mellon University, Pittsburgh

Caceres MD, Legendre P. 2009. Associations between species and groups of sites: Indices and statistical inference. Ecology 90 (12): 3566-3574.

Cámara-Leret, Rodrigo, Dennehy z. 2019. Indigenous knowledge of New Guinea's useful plants: A review. Econ Bot 73 (3): 405-415.

Cámara-Leret, Rodrigo, Frodin DG, Adema F, Anderson C, Appelhans MS, Argent G, Guerrero SA, Ashton P, Baker WJ, Barfod AS, Barrington D, Borosova R, Bramley GLC, Briggs M, Buerki S, Cahen B, Callmander MW, Cheek M, Cheng-Wei C, Conn BJ, Coode MJE, Darbyshire I, Dawson S, Dransfield J, Drinkell C, Duyfjes B, Ebihara A, Ezedin Z, Long-Fei F, Gideon O, Girmansyah D, Govaerts R, Fortune-Hopkins H, Hassemer G, Hay A, Heatubun CD, Hind DJN, Hoch P, Homot P, Hovenkamp P, Hughes M, Jebb M, Jennings L, Jimbo T, Kessler M, Kiew R, Knapp S, Lamei P, Lehnert M, Lewis GP, Linder HP, Lindsay S, Low TW, Lucas E, Mancera JP, Monro AK, Moore A, Middleton DJ, Nagamasu H, Newman MF, Lughadha EN, Melo PHA, Ohlsen DJ, Pannell CM, Parris B, Pearce L, Penneys DS, Perrie LR, Petoe P, Poulsen AD, Prance GT, Quakenbush JP, Raes N, Rodda M, Rogers ZS, Schuiteman A, Schwartsburd P, P Scotland RW, Simmons MP, Simpson DA, Stevens P, Sundue M, Testo W, Trias-Blasi A, Turner I, Utteridge T, Walsingham L, Webber BL, Wei R, Weiblen GD, Weigend M, Weston P, de Wilde W, Wilkie P, Wilmot-Dear CM, Wilson HP, Wood JRI, Li-Bing Z, van Welzen PC. 2020. New Guinea has the world's richest island. Nature 1-5.

Carreño-Rocabado G, Peña-ClaroM, Bongers F, Alarcón A, Licona JC, Poorter L. 2012. Effects of disturbance intensity on species and functional diversity in a tropical forest. J Ecol 100 (6): 1453-1463.

Castilla, Antonio R, Pope N, Jha S. 2016. Positive density-dependent reproduction regulated by local Kinship and size in an understorey tropical tree. Ann Bot 117 (2): 319-329.

Chazdon RL. 2003. Tropical forest recovery: Legacies of human impact and natural disturbances. Perspect Plant Ecol Evol Syst 6 (1-2): 5171.

Cirimwam, L, Doumenge C, Kahindo JM, Amani C. 2019. The effect of elevation on species richness in tropical forests depends on the considered lifeform: Results from an East African Mountain Forest. Trop Ecol 60 (4): 473-484.

Dezzotti A, Mortoro A, Medina A, Sbrancia R, Beltrán HA. 2019. Plant richness and life form diversity along vegetation and forest use gradients in Northwestern Patagonia of Argentina. Cerne 25 (3): 301 313.

Farneda FZ, Rocha R, López-Baucells A, Sampaio EM, Palmeirim JM, Bobrowiec PED, Grelle CEV, Meyer CFJ. 2018. Functional recovery of Amazonian bat assemblages following secondary forest succession. Biol Conserv 218: 192-199.

Fatem, Marten S, Djitmau DA, Ungirwalu A, Wanma OA, Simbiak VI, Benu NMH, Tambing J, Murdjoko A. 2020. Species diversity, composition, and heterospecific associations of trees in three altitudinal gradients in bird's head peninsula, Papua, Indonesia. Biodiversitas 21 (8): 3596-3605.

Fernández-Lugo S, De Nascimento L, Méndez J, González-Delgado G, Gomes EPC, Otto R, Arévalo JR, Fernández-Palacios JM. 2015. Seedling survival patterns in Macaronesian laurel forest: A long-term study in Tenerife (Canary Islands). Forestry 88 (1): 121-130.

Givnish TJ. 1999. On the causes of gradients in tropical tree diversity. J Ecol 87 (2): 193-210.

Goodale UM, Ashton MS, Berlyn GP, Gregoire TG, Singhakumara BMP, Tennakoon KU. 2012. Disturbance and tropical pioneer species: Patterns of association across life-history stages. For Ecol Manag 277: 54-66.

Gustafsson, Malin, Gustafsson L, Alloysius D, Falck J, Yap S, Karlsson A, Ilstedt U. 2016. Life-history traits predict the response to increased light among 33 tropical rainforest tree species. For Ecol Manag 362: 20-28.

Houter NC, Pons TL. 2014. Gap effects on leaf traits of tropical rainforest trees differing in juvenile light requirement. Oecologia 175 (1): 37 50 . 
Hunter, Maria O, Keller M, Morton D, Cook B, Lefsky M, Ducey M, Saleska S, De Oliveira RS, Schietti J, Zang R. 2015. Structura dynamics of tropical moist forest gaps. PLoS ONE 10 (7): 1-19. DOI: 10.1371/journal.pone.0132144

Itoh, Akira, Yamakura T, Ogino K, Lee HS, Ashton PS. 1997. Spatial distribution patterns of two predominant emergent trees in a tropical rainforest in Sarawak, Malaysia. Plant Ecol 132 (2): 121-136.

Johnson, Daniel J, Condit R, Hubbell SP, Comita LS. 2017. Abiotic niche partitioning and negative density dependence drive tree seedling survival in a tropical forest. Proc R Soc B: Biol Sci 284 (1869): 20172210. DOI: 10.1098/rspb.2017.2210

Kartikasari SN, Marshall AJ, Beehler B. 2012. Ekologi Papua. Seri Ekologi Indonesia, Jilid VI. Yayasan Obor Indonesia dan Conservation International, Jakarta. [Indonesian]

Laurans M, Hérault B, Vieilledent G, Vincent G. 2014. Vertical stratification reduces competition for light in dense tropical forests. For Ecol Manag 329: 79-88.

Legendre, Pierre, Fortin MJ. 1989. Spatial pattern and ecological analysis. Vegetatio 80 (2): 107-138

Liu JJ, Slik JWF. 2014. Forest fragment spatial distribution matters for tropical tree conservation. Biol Conserv 171: 99-106.

Lü XT, Tang JW. 2010. Structure and composition of the understory treelets in a non-dipterocarp forest of tropical Asia. For Ecol Manag 260 (4): 565-572.

Magrach, Ainhoa, Rodríguez-Pérez J, Campbell M, Laurance WF. 2014 Edge effects shape the spatial distribution of lianas and epiphytic ferns in Australian tropical rain forest fragments. Appl Veg Sci 17 (4): 754-764

Menezes GSC, Cazetta E, Dodonov P. 2019. Vegetation structure acros fire edges in a neotropical rain forest. For Ecol Manag 453:117587.

Montesinos-Navarro A, Estrada A, Font X, Matias MG, Meireles C, Mendoza M, Honrado JP, Prasad HD, Vicente JR, Early R. 2018 Community structure informs species geographic distributions. PLoS One 13 (5): 1-16. DOI: 10.1371/journal.pone.0197877

Montgomery RA, Chazdon RL. 2001. Forest structure, canopy architecture, and light transmittance in tropical wet forests. Ecology 82 (10): 2707- 2718

Murdjoko, Agustinus, Marsono D, Sadono R, Hadisusanto S. 2016a. Plant species composition and their conspecific association in natural tropical rainforest, South Papua. Biosaintifika J Biol Biol Educ 8(1): $33-47$.

Murdjoko, Agustinus, Marsono D, Sadono R, Hadisusanto S. 2016b. Tree association with Pometia and its structure in logging concession of South Papua forest. Jurnal Manajemen Hutan Tropika (Journal of Tropical Forest Management) 22 (3): 180-191. [Indonesian]

Murdjoko, Agustinus, Marsono D, Sadono R, Hadisusanto S. 2017. Recovery of residual forest ecosystem as an impact of selective logging in South Papua: An ecological approach. Biotropia 24 (3): 230-245

Oksane, J, Roeland KF, Blanchet G, Legendre P, Minchin PR, O'Hara RB, Simpson GL, Solymos P, Wagner HM, Stevens HH. 2019. Package 'Vegan.' R Package Version 3.4.0.

Padmanaba M, Corlett RT. 2014. Minimizing risks of invasive alien plan species in tropical production forest management. Forests 5 (8): 1982-1998.

Pan, Yude, Birdsey RA, Phillips OL, Jackson RB. 2013. The structure, distribution, and biomass of the world's forests. Ann Rev Ecol Evol Syst 44 (1): 593-622

Piotto D, Craven D, Montagnini F, Ashton M, Oliver C, Thomas WW. 2019. Successional, spatial, and seasonal changes in seed rain in the Atlantic forest of Southern Bahia, Brazil. PLoS ONE 14 (12): 1-15. DOI: 10.1371 /journal.pone.0226474

Rahman MM, Tsukamoto J. 2015. Opposing effects of substrate quality and site factors on forest floor turnover rates: An example from the tropics. Forestry 88 (2): 190-199

Robiansyah I. 2018. Diversity and biomass of tree species in Tambrauw, West Papua, Indonesia. Biodiversitas 19 (2): 377-386.

Rüger N, Berger U, Hubbell SP, Vieilledent G, Condit R. 2011. Growth strategies of tropical tree species: Disentangling light and size effects. PLoS ONE 6 (9): e25330. DOI: 10.1371/journal.pone.0025330

Sawada Yoshimi, Shin-ichiro A, Takyu M, Repin R, Nais J, Kitayama K, 2015. Community dynamics over 14 years along gradients of geological substrate. J Trop Ecol 31 (2): 117-128.

Sebbenn AM, Degen B, Azevedo VCR, Silva MB, de Lacerda AEB, Ciampi AY, Kanashiro M, da S. Carneiro F, Thompson I, Loveless. 2008 MD. Modelling the long-term impacts of selective logging on genetic diversity and demographic structure of four tropical tree species in the Amazon forest. For Ecol Manag 254 (2): 335-349.

Seidler TG, Plotkin JB. 2006. Seed dispersal and spatial pattern in tropical trees. PLoS Biol 4 (11): e344. DOI: 10.1371/journal.pbio.0040344.

Slik JWF, Arroyo-Rodríguez V, Aiba SI, Alvarez-Loayza P, Alves LF, Ashton P, Balvanera P, Bastian ML, Bellingham PJ, Van Den Berg E, Bernacci L, Da Conceição Bispo P, Blanc L, Böhning-Gaese K, Boeckx P, Bongers F, Boyle B, Bradford M, Brearley FQ, Hockemba MBN, Bunyavejchewin S, Matos DCL, Castillo-Santiago M, Catharino ELM, Chai SL, Chen Y, Colwell RK, Robin CL, Clark C, Clark DB, Clark DA, Culmsee H, Damas K, Dattaraja HS, Dauby G, Davidar P, DeWalt SJ, Doucet JL, Duque A, Durigan G, Eichhorn KAO, Eisenlohr PV, Eler E, Ewango C, Farwig N, Feeley KJ, Ferreira L, Field R, De Oliveira Filho AT, Fletcher C, Forshed O, Franco G, Fredriksson G, Gillespie T, Gillet JF, Amarnath G, Griffith DM, Grogan J, Gunatilleke N, Harris D, Harrison R, Hector A, Homeier J, Imai N, Itoh A, Jansen PA, Joly CA, De Jong BHJ, Kartawinata K, Kearsley E, Kelly DL, Kenfack D, Kessler M, Kitayama K, Kooyman R, Larney E, Laumonier Y, Laurance S, Laurance WF, Lawes MJ, Do Amaral IL, Letche SG, Lindsell J, Lu X, Mansor A, Marjokorpi A, Martin EH, Meilby H, Melo FPL, Metcalfe DJ, Medjibe VP, Metzger JP, Millet J, Mohandass D, Montero JC, De Morisson Valeriano M, Mugerwa B, Nagamasu H, Nilus R, Ochoa-Gaona S, Onrizal, Page P, Parolin P, Parren M, Parthasarathy N, Paudel E, Permana A, Piedade MTF, Pitman NCA, Poorter L, Poulsen AD, Poulsen J, Powers J, Prasad RC, Puyravaud JP, Razafimahaimodison JC, Reitsma J, Dos Santos JR, Spironello WR, Romero-Saltos H, Rovero F, Rozak AH, Ruokolainen K, Rutishauser E, Saiter F, Saner P, Santos BA, Santos F, Sarker SK, Satdichanh M, Schmitt CB, Schöngart J, Schulze M, Suganuma MS, Sheil D, Da Silva Pinheiro E, Sist P, Stevart T, Sukumar R, Sun IF, Sunderand T, Suresh HS, Suzuki E, Tabarelli M, Tang J, Targhetta N, Theilade I, Thomas DW, Tchouto P, Hurtado J, Valencia R, Van Valkenburg JLCH, Van Do T, Vasquez R, Verbeeck H, Adekunle V, Vieira SA, Webb CO, Whitfeld T, Wich SA, Williams J, Wittmann F, Wöll H, Yang X, Yao CYA, Yap SL, Yoneda T, Zahawi RA, Zakaria R, Zang R, De Assis RL, Luize BG, Venticinque EM. 2015. An estimate of the number of tropical tree species. Proc Nat Acad Sci USA 112 (24): 7472-7477.

Slik JWF, Franklin J, Arroyo-Rodríguez V, Field R, Aguilar S, Aguirre N, Ahumada J, Aiba SI, Alves LF, Anitha K, Avella A, Mora F, Aymard GAC, Báez S, Balvanera P, Bastian ML, Bastin JF, Bellingham PJ, Van Den Berg E, Da Conceição Bispo P, Boeckx P, Boehning-Gaese K, Bongers F, Boyle F, Brambach F, Brearley FQ, Brown S, Chai SL, Chazdon RL, Chen S, Chhang P, Chuyong G, Ewango C, Coronado IM, Cristóbal-Azkarate J, Culmsee H, Damas K, Dattaraja HS, Davidar P, DeWalt SJ, Din H, Drake DR, Duque A, Durigan G, Eichhorn K, Eler ES, Enoki T, Ensslin A, Fandohan AB, Farwig N, Feeley KJ, Fischer M, Forshed O, Garcia QS, Garkoti SC, Gillespie TW, Gillet JF, Gonmadje C, Granzow-De La Cerda I, Griffith DM, Grogan J, Hakeem KR, Harris DJ, Harrison RD, Hector A, Andreas Hemp, Jürgen Homeier, M. Shah Hussain, Guillermo IbarraManríquez, I. Faridah Hanum, Nobuo Imai, Jansen PA, Joly CA, Joseph S, Kartawinata K, Kearsley E, Kelly DL, Kessler M, Killeen TJ, Kooyman RM, Laumonier Y, Laurance SG, Laurance WF, Lawes MJ, Letcher SG, Lindsell J, Lovett J, Lozada J, Lu X, Lykke AM, Bin Mahmud K, Mahayani NPD, Mansor A, Marshall AR, Martin EH, Matos DCL, Meave JA, Melo FPL, Mendoza ZHM, Metali M, Medjibe VP, Metzger JP, Metzker T, Mohandass D, Munguía-Rosas MA, Muñoz R, Nurtjahya E, Eddie Lenza De Oliveira, Onrizal, Pia Parolin, Marc Parren, N. Parthasarathy, Ekananda Paudel, Rolando Perez, Pérez-García EA, Pommer U, Poorter L, Qi L, Piedade MTF, Pinto JRR, Poulsen AD, Poulsen JR, Powers JS, Prasad RC, Puyravaud JP, Rangel O, Reitsma J, Rocha DSB, Rolim S, Rovero F, Rozak A, Ruokolainen K, Rutishauser E, Rutten G, Said MNM, Saiter FZ, Saner P, Santos B, Dos Santos JR, Sarker SK, Schmitt CB, Schoengart J, Schulze M, Sheil D, Sist P, Souza AF, Spironello WR, Sposito T, Steinmetz R, Stevart T, Suganuma MS, Sukri R, Sultana A, Sukumar R, Sunderland T, Supriyadi, Suresh HS, Suzuki E, Tabarelli M, Tang J, Tanner EVJ, Targhetta N, Theilade I, Thomas D, Timberlake J, De Morisson Valeriano M, Van Valkenburg J, Van Do T, Van Sam H, Vandermeer JH, Verbeeck H, Vetaas OR, Adekunle V, Vieira SA, Webb CO, Webb EL, Whitfeld T, Wich S, Williams J, Wiser S, Wittmann F, Yang X, Yao CYA, Yap SL, Zahawi RA, Zakaria R, Zang R. 2018. Phylogenetic classification of the world's tropical forests. Proc Nat Acad Sci USA 115 (8): 1837-1842. 
Steege HT, Henkel TW, Helal N, Marimon BS, Marimon-Junior BN, Huth A, Groeneveld J, Sabatier D, de Souza Coelho L, de Andrade LFD, Salomão RP, Amaral IL, de Almeida MFD, Castilho CV, Phillips OL, Guevara JE, de Jesus VCM, López DC, Magnusson WE, Wittmann F, Irume MV, Martins MP, da Silva GSR, Molino JF, Bánki OS, Piedade MTF, Pitman NCA, Mendoza AM, Ramos JF, Luize BG, de Leão NEMM, Vargas PN, Silva TSF, Venticinque EM, Manzatto AG, Reis NFC, Terborgh J, Casula KR, Coronado ENH, Montero JC, Feldpausch TR, Duque A, Costa FRC, Arboleda NC, Schöngart J, Killeen TJ, Vasquez R, Mostacedo B, Demarchi LO, Assis RL, Baraloto C, Engel J, Petronelli P, Castellanos P, de Medeiros MB, Quaresma A, Simon MF, Andrade A, Camargo JL, Laurance SGW, Laurance WF, Rincón LM, Schietti J, Sousa TR, de Sousa FE, Lopes MA, Magalhães JLL, Nascimento HEM, de Queiroz HL, Aymard CGA, Brienen R, Revilla JDC, Vieira ICG, Cintra BBL, Stevenson PR, Feitosa YO, Duivenvoorden JF, Mogollón HF, Araujo-Murakami A, Ferreira LV, Lozada JR, Comiskey JA, de Toledo JJ, Damasco G, Dávila N, Draper F, García-Villacorta R, Lopes A, Vicentini A, Alonso A, Dallmeier F, Gomes VHF, Lloyd J, Neill D, de Aguiar DPP, Arroyo L, Carvalho FA, de Souza FC, do Amaral DD, Feeley KJ, Gribel R, Pansonato MP, Barlow J, Berenguer E, Ferreira J, Fine PVA, Guedes MCA, Jimenez EM, Licona JC, Mora MCP, Villa B, Cerón C, Maas P, Silveira M, Stropp J, Thomas R, Baker TR, Daly D, Dexter KG, HuamantupaChuquimaco I, Milliken W, Pennington T, Paredes MR, Fuentes A, Klitgaard B, Pena JJM, Peres CA, Silman MR, Tello JS, Chave J, Valverde FC, Di Fiore A, Hilário RR, Phillips JF, Rivas-Torres G, van Andel TR, von Hildebrand P, Noronha JC, Barbosa EM, Barbosa FR, de Matos BLC, de Sá Carpanedo R, Doza HPD, Fonty E, Zárate RG, Gonzales T, Gonzales GPG, Hoffman B, Junqueira AB, Malhi Y, de Andrade MIP, Pinto LFM, Prieto A, de Jesus RD, Rudas A, Ruschel AR, Silva N, Vela CIA, Vos VA, Zent EL, Zent S, Albuquerque BW, Cano A, Márquez YAC, Correa DF, Costa JBP, Flores BM, Galbraith D, Holmgren M, Kalamandeen M, Nascimento
MT, Oliveira AA, Ramirez-Angulo H, Rocha M, Scudeller VV, Sierra R, Tirado M, Medina MNU, van der Heijden G, Torre EV, Vriesendorp C, Wang O, Young KR, Reategui MAA, Baider C, Balslev H, Cárdenas S, Casas LF, Farfan-Rios W, Ferreira C, Linares-Palomino R, Mendoza C, Mesones I, Torres-Lezama A, Giraldo LEU, Villarroel D, Zagt R, Alexiades MN, de Oliveira EA, Garcia-Cabrera K, Hernandez L, Cuenca WP, Pansini S, Pauletto D, Arevalo FR, Sampaio AF, Sandoval EHV, Gamarra LV, Levesley A, Pickavance G, Melgaço K. 2019. Rarity of monodominance in hyperdiverse Amazonian Forests. Sci Rep 9 (1): 1-15.

Swaine MD, Lieberman D, Putz FE. 1987. The dynamics of tree populations in tronical forest: A review. J Trop Ecol 3 (4): 359-366.

Ter Braak CJF. 1986. Canonical correspondence analysis: A new eigenvector technique for multivariate direct gradient analysis. Ecology 67 (5): 1167-1179.

Thomas SC, Baltzer JL. 2002. Tropical Forests. Encyclopedia of Life Sciences 1-8.

Vergara-Rodrígue D, Mathieu G, Samain MS, Armenta-Montero S, Krömer T. 2017. Diversity, distribution, and conservation status of Peperomia (Piperaceae) in the State of Veracruz, Mexico. Trop Conserv Sci 10 (44): 1-18.

Vitousek, Peter M. 1984. Litterfall, nutrient cycling, and nutrient limitation in tropical forests. Ecology 65 (1): 285-298.

Wang, Hongxiang, Peng H, Hui G, Hu Y, Zhao Z. 2018. Large trees are surrounded by more heterospecific neighboring trees in Korean pine broad-leaved natural forests. Sci Rep 8 (1): 1-11.

Wright SJ, Muller-Landau HC. 2006. The uncertain future of tropical forest species. Biotropica 38 (4): 443-445.

Yamamoto, Shin-Ichi. 2000. Forest gap dynamics and tree regeneration. J For Res 5 (4): 223-229.

Zhu, Yan, Comita LS, Hubbell SP, Keping Ma. 2015. Conspecific and phylogenetic density-dependent survival differs across life stages in a tropical forest. J Ecol 103 (4): 957-966. 
Table S1. Species name of heterospecific associations for understory for Figure 2

\begin{tabular}{|c|c|c|c|c|c|}
\hline No. & Code & Species & Group 1 & Group 2 & Group 3 \\
\hline 1 & Kiba_co & Kibara coriacea (Blume) Hook. f. \& A. Thomps. & + & & \\
\hline 2 & Rhus_la & Rhus lamprocarpa Merr. \& L.M.Perry & + & & \\
\hline 3 & Dios_pi & Diospyros pilosanthera Blanco & + & & \\
\hline 4 & Lits_le & Litsea ledermannii Teschner & + & & \\
\hline 5 & Maca_gi & Macaranga gigantea (Rchb.f. \& Zoll.) Müll.Arg. & + & & \\
\hline 6 & Maca_ta & Macaranga tanarius (L.) Müll.Arg. & + & & \\
\hline 7 & Seme_pa & Semecarpus papuana Lauterb. & + & & \\
\hline 8 & Ster_sh & Sterculia shillinglawii F.Muell. & + & & \\
\hline 9 & Case_ca & Casearia carrii Sleumer & + & & \\
\hline 10 & Xant_no & Wendlandia $\mathrm{sp}$ & + & & \\
\hline 11 & Teij_bo & Teijsmanniodendron bogoriense Koord. & + & & \\
\hline 12 & Flin_pi & Flindersia pimenteliana F.Muell. & + & & \\
\hline 13 & Case_sp & Casearia sp & + & & \\
\hline 14 & Hapl_ce & Haplolobus celebicus H.J.Lam & + & & \\
\hline 15 & Myri_en & Myristica ensifolia J.Sinclair & + & & \\
\hline 16 & Octa_in & Octamyrtus insignis Diels & + & & \\
\hline 17 & Piso_lo & Pisonia longirostris Teijsm. \& Binn. & + & & \\
\hline 18 & Wend_sp & Wendlandia sp & + & & \\
\hline 19 & Timo_ca & Timonius carii S.P.Darwin & + & & \\
\hline 20 & Prun_ja & Prunus javanica (Teijsm. \& Binn.) Miq. & + & & \\
\hline 21 & Hapl_fl & Haplolobus floribundus (K.Schum.) H.J.Lam & + & & \\
\hline 22 & Anti_de & Alstonia spectabilis $\mathrm{R} . \mathrm{Br}$. & + & & \\
\hline 23 & Buch_ar & Buchanania arborescens (Blume) Blume & + & & \\
\hline 24 & Cryp_pa & Cryptocarya palmerensis C.K.Allen & + & & \\
\hline 25 & Gmel_se & Gmelina sessilis C.T.White \& W.D.Francis ex Lane-Poole & + & & \\
\hline 26 & Garc_pi & Garcinia picrorhiza Miq. & + & & \\
\hline 27 & Para_ve & Parastemon versteeghii Merr. \& L.M.Perry & + & & \\
\hline 28 & Knem_in & Knema intermedia Warb. & + & & \\
\hline 29 & Case_mo & Casearia monticola Sleumer & + & & \\
\hline 30 & Half_ke & Halfordia kendack Guillaumin & + & & \\
\hline 31 & Syzy_ve & Syzygium versteegii (Lauterb.) Merr. \& L.M.Perry & + & & \\
\hline 32 & Ficu_ro & Ficus robusta Corner & + & & \\
\hline 33 & Heri_sy & Heritiera sylvatica S.Vidal & + & & \\
\hline 34 & Cerb_fl & Cerbera floribunda K.Schum. & + & & \\
\hline 35 & Myri_gl & Myristica globosa Warb. & + & & \\
\hline 36 & Dryp_gl & Drypetes globosa (Merr.) Pax \& K.Hoffm. & + & & \\
\hline 37 & Phal_ma & Phaleria macrocarpa (Scheff.) Boerl. & + & & \\
\hline 38 & Cana_ri & Canarium rigidum (Blume) Zipp. ex Miq. & + & & \\
\hline 39 & Lits_ti & Litsea timoriana Span. & + & & \\
\hline 40 & Timo_ti & Timonius timon (Spreng.) Merr. & + & & \\
\hline 41 & Homa_fo & Heritiera sylvatica $\mathrm{S}$.Vidal & + & & \\
\hline 42 & Endo_me & Endospermum medullosum L.S.Sm. & + & & \\
\hline 43 & Pome_pi & Pometia pinnata J.R.Forst. \& G.Forst. & + & & \\
\hline 44 & Kiba_bu & Kibara bullata Philipson & + & & \\
\hline 45 & Drac_da & Dracontomelon dao (Blanco) Merr. \& Rolfe & + & & \\
\hline 46 & Goni_gi & Goniothalamus giganteus Hook.f. \& Thomson & + & & \\
\hline 47 & Nauc_or & Nauclea orientalis (L.) L. & + & & \\
\hline 48 & Beil_mo & Beilschmiedia morobensis Kosterm. & + & & \\
\hline 49 & Cara_br & Carallia brachiata (Lour.) Merr. & + & & \\
\hline 50 & Lits_sp & Litsea $\mathrm{sp}$ & + & & \\
\hline 51 & Pime_am & Pimelodendron amboinicum Hassk. & + & & \\
\hline 52 & Medu_la & Medusanthera laxiflora (Miers) R.A.Howard & + & & \\
\hline 53 & Myri_fa & Myristica fatua Houtt. & + & & \\
\hline 54 & Gono_li & Gonocaryum litorale (Blume) Sleumer & + & & \\
\hline 55 & Lith_ru & Lithocarpus rufovillosus (Markgr.) Rehder & + & & \\
\hline 56 & Hope_pa & Hopea papuana Diels & + & & \\
\hline 57 & Dill_pa & Dillenia papuana Martelli & + & & \\
\hline 58 & Mast_pa & Mastixiodendron pachyclados (K.Schum.) Melch. & + & & \\
\hline 59 & Pome_ac & Pometia acuminata Radlk. & + & & \\
\hline 60 & Kiba_el & Kibara elongata A.C.Sm. & + & & \\
\hline 61 & Clei_pa & Cleistanthus papuanus (Lauterb.) Jabl. & + & & \\
\hline 62 & Ints_pa & Intsia palembanica Miq. & + & & \\
\hline 63 & Galb_be & Galbulimima belgraveana (F.Muell.) Sprague & + & & \\
\hline
\end{tabular}


65 Giro_ne Gironniera nervosa Planch.

66 Mani_pl Maniltoa plurijuga Merr. \& L.M.Perry

67 Hope_ce Hopea celtidifolia Kosterm.

68 Meli_el

Garc_sp

Pala_lo

Melicope elleryana (F. Muell.) T.G. Hartley

Garcinia sp

Camp_br Campnosperma brevipetiolatum Volkens

Ster_ma Sterculia macrophylla Vent.

Harp_ca Harpullia carrii Leenh.

Hors_la Horsfieldia laevigata Warb.

Arch_pa Archidendron parviflorum Pulle

Chry_pa Chrysophyllum papuanicum (Pierre ex Dubard) Royen

Fagr_ra Fagraea racemosa Jack

Klei_ho Kleinhovia hospita L.

Endi_ru Endiandra rubescens (Blume) Miq.

Tris_ma Tristaniopsis macrosperma (F.Muell.) Peter G.Wilson \& J.T.Waterh.

Cory_la Corynocarpus laevigatus J.R.Forst. \& G.Forst.

Cryp_sp Cryptocarya sp

Tabe_au Tabernaemontana aurantiaca Gaudich.

Mall_sp_Mallotus sp

Deca_pa Decaspermum parviflorum (Lam.) A.J.Scott

Agla_sp Aglaia spectabilis (Miq.) S.S.Jain \& S.Bennet

Rapa_te Rapanea tempanpan P.Royen

Calo_ca Calophyllum caudatum Kaneh. \& Hatus.

Xant_pa Xanthophyllum papuanum Whitmore ex Meijden

Hapl_la Haplolobus lanceolatus H.J.Lam ex Leenh.

Alst_sp Alstonia spectabilis R.Br.

Dios_sp Diospyros sp

Elae_an Elaeocarpus angustifolius Blume

Rypa_ja Ryparosa javanica Koord. \& Valeton

Rhod_ci Rhodamnia cinerea Jack

Myri_gi Myristica gigantea King

Anti_to Antiaris toxicaria Lesch.

Calo_in Calophyllum inophyllum $\mathrm{L}$.

Para_pr Pararchidendron pruinosum (Benth.) I.C.Nielsen

Siphonodon celastrineus Griff.

Siphonodon sp

Siph_sp

Maasia glauca (Hassk.) Mols, Kessler \& Rogstad

Terminalia kaernbacchii Warb.

Term_ka

Spat_ja

Spathiostemon javensis Blume

105 Dyso_mo Dysoxylum mollissimum Blume

106 Plan_ke Planchonella keyensis H.J.Lam

107 Ficu_sp Ficus sp

108 Hors_pa Horsfieldia parviflora (Roxb.) J.Sinclair 
Table S2. Species name of heterospecific associations for upper story Figure 3

\begin{tabular}{|c|c|c|c|c|c|c|}
\hline No. & Code & Species & Group 1 & Group 2 & Group 3 & Group 4 \\
\hline 1 & Hors_ir & Horsfieldia irya (Gaertn.) Warb. & & + & & \\
\hline 2 & Garc_la & Garcinia latissima Miq. & & + & & \\
\hline 3 & Alst_sc & Alstonia scholaris (L.) R. Br. & & + & & \\
\hline 4 & Endi_vi & Endiandra virens F.Muell. & & + & & \\
\hline 5 & Sloa_pu & Sloanea pullei O.C.Schmidt ex A.C.Sm. & & + & & \\
\hline 6 & Galb_be & Galbulimima belgraveana (F.Muell.) Sprague & & + & & \\
\hline 7 & Pome_ac & Pometia acuminata Radlk. & & + & & \\
\hline 8 & Chis_ce & Chisocheton ceramicus Miq. & & + & & \\
\hline 9 & Dyso_mo & Dysoxylum mollissimum Blume & & + & & \\
\hline 10 & Endo_me & Endospermum medullosum L.S.Sm. & & + & & \\
\hline 11 & Pime_am & Pimelodendron amboinicum Hassk. & & + & & \\
\hline 12 & Gono_li & Gonocaryum littorale (Blume) Sleumer & + & & & \\
\hline 13 & Stre_el & Streblus elongatus (Miq.) Corner & + & & & \\
\hline 14 & Homa_fo & Heritiera sylvatica S.Vidal & + & & & \\
\hline 15 & Gnet_gn & Gnetum gnemon L. & + & & & \\
\hline 16 & Homa_no & Homalanthus novoguineensis (Warb.) K.Schum. & + & & & \\
\hline 17 & Cory_la & Corynocarpus laevigatus J.R.Forst. \& G.Forst. & + & & & \\
\hline 18 & Drac_da & Dracontomelon dao (Blanco) Merr. \& Rolfe & + & & & \\
\hline 19 & Cana_od & Canarium indicum $\mathrm{L}$. & + & & & \\
\hline 20 & Pter_be & Pterocymbium beccarii K.Schum. & + & & & \\
\hline 21 & Pala_lo & Palaquium lobbianum Burck & + & & & \\
\hline 22 & Cana_in & Canarium indicum $\mathrm{L}$. & + & & & \\
\hline 23 & Cara_br & Carallia brachiata (Lour.) Merr. & + & & & \\
\hline 24 & Timo_ca & Timonius carii S.P.Darwin & + & & & \\
\hline 25 & Hors_sy & Horsfieldia sylvestris Warb. & + & & & \\
\hline 26 & Maas_su & Maasia sumatrana (Miq.) Mols, Kessler \& Rogstad & + & & & \\
\hline 27 & Hope_pa & Hopea papuana Diels & + & & & \\
\hline 28 & Hope_ce & Hopea celtidifolia Kosterm. & + & & & \\
\hline 29 & Rhus_ta & Rhus taitensis Guill. & + & & & \\
\hline 30 & Acti_ni & Actinodaphne nitida Teschner & + & & & \\
\hline 31 & Dill_pa & Dillenia papuana Martelli & + & & & \\
\hline 32 & Medu_la & Medusanthera laxiflora (Miers) R.A.Howard & + & & & \\
\hline 33 & Teij_bo & Teijsmanniodendron bogoriense Koord. & + & & & \\
\hline 34 & Tris_ma & Tristaniopsis macrosperma (F.Muell.) Peter G.Wilson \& J.T.Waterh. & + & & & \\
\hline 35 & Call_lo & Callicarpa longifolia Lam. & + & & & \\
\hline 36 & Comm_ba & Commersonia bartramia (L.) Merr. & + & & & \\
\hline 37 & Dios_pi & Diospyros pilosanthera Blanco & + & & & \\
\hline 38 & Knem_in & Knema intermedia Warb. & + & & & \\
\hline 39 & Dryp_gl & Drypetes globosa (Merr.) Pax \& K.Hoffm. & + & & & \\
\hline 40 & Cryp_pa & Cryptocarya palmerensis C.K.Allen & + & & & \\
\hline 41 & Meli_el & Melicope elleryana (F. Muell.) T.G. Hartley & + & & & \\
\hline 42 & Lits_ti & Litsea timoriana Span. & + & & & \\
\hline 43 & Siph_ce & Siphonodon celastrineus Griff. & + & & & \\
\hline 44 & Siph_sp & Siphonodon sp & + & & & \\
\hline 45 & Vite_pi & Vitex pinnata $\mathrm{L}$ & + & & & \\
\hline 46 & Poly_no & Polyscias nodosa (Blume) Seem. & + & & & \\
\hline 47 & Pome_pi & Pometia pinnata J.R.Forst. \& G.Forst. & + & & & \\
\hline 48 & Agla_ar & Aglaia argentea Blume & + & & & \\
\hline 49 & Acro_sp & Acronychia $\mathrm{sp}$ & + & & & \\
\hline 50 & Gmel_se & Gmelina sessilis C.T.White \& W.D.Francis ex Lane-Poole & + & & & \\
\hline 51 & Mani_br & Maniltoa browneoides Harms & + & & & \\
\hline 52 & Prun_ar & Prunus arborea (Blume) Kalkman & + & & & \\
\hline 53 & Camp_br & Campnosperma brevipetiolatum Volkens & + & & & \\
\hline 54 & Hors_la & Horsfieldia laevigata Warb. & + & & & \\
\hline 55 & Cana_hi & Campnosperma brevipetiolatum Volkens & + & & & \\
\hline 56 & Deca_pa & Decaspermum parviflorum (Lam.) A.J.Scott & + & & & \\
\hline 57 & Calo_in & Calophyllum inophyllum $\mathrm{L}$. & + & & & \\
\hline 58 & Heri_sy & Heritiera sylvatica S.Vidal & + & & & \\
\hline 59 & Clei_pa & Cleistanthus papuanus (Lauterb.) Jabl. & + & & & \\
\hline 60 & Elae_an & Elaeocarpus angustifolius Blume & + & & & \\
\hline 61 & Gymn_fa & Gymnacranthera farquhariana (Hook.f. \& Thomson) Warb. & + & & & \\
\hline 62 & Grew_er & Grewia eriocarpa Juss. & + & & & \\
\hline 63 & Xant_no & Wendlandia $\mathrm{sp}$ & + & & & \\
\hline
\end{tabular}


65 Arto_al Artocarpus altilis (Parkinson ex F.A.Zorn) Fosberg

66 Para_pr Pararchidendron pruinosum (Benth.) I.C.Nielsen

67 Plan_ke Planchonella keyensis H.J.Lam

68 Dios_pa Diospyros papuana Valeton ex Bakh.

69 Ochr_gl Ochrosia glomerata (Blume) F.Muell.

70 Myri_fa Myristica fatua Houtt.

71 Ster_sh Sterculia shillinglawii F.Muell.

72 Syzy_sp2 Syzygium sp2

73 Syzy_sp3 Syzygium $\mathrm{sp3}$

74 Xant_pa Xanthophyllum papuanum Whitmore ex Meijden

75 Euca_pa Eucalyptopsis papuana C.T.White

76 Flin_pi Flindersia pimenteliana F.Muell.

77 Hapl_fl Haplolobus floribundus (K.Schum.) H.J.Lam

78 Lits_fi Litsea firma (Blume) Hook.f.

79 Term_co Terminalia copelandi Elmer

80 Calo_ca Calophyllum caudatum Kaneh. \& Hatus.

81 Coch_gi Cochlospermum gillivraei Benth.

82 Buch_ar Buchanania arborescens (Blume) Blume

83 Fagr_el Fagraea elliptica Roxb.

84 Prun_ja Prunus javanica (Teijsm. \& Binn.) Miq.

85 Endi_ru Endiandra rubescens (Blume) Miq. 
Table S3. Species name of conspecific associations Figure 4. The S stands for small individuals and L symbolizes large individuals.

\begin{tabular}{|c|c|c|c|}
\hline No. & Code & & Species \\
\hline 1 & Agla_ar & _L & Aglaia argentea Blume \\
\hline 2 & Agla_ar & S & Aglaia argentea Blume \\
\hline 3 & Buch_ar & L & Buchanania arborescens (Blume) Blume \\
\hline 4 & Buch_ar & _S & Buchanania arborescens (Blume) Blume \\
\hline 5 & Calo_ca & _L & Calophyllum caudatum Kaneh. \& Hatus. \\
\hline 6 & Calo_ca & S & Calophyllum caudatum Kaneh. \& Hatus. \\
\hline 7 & Calo_in & L & Calophyllum inophyllum $\mathrm{L}$. \\
\hline 8 & Calo_in & _S & Calophyllum inophyllum $\mathrm{L}$. \\
\hline 9 & Camp_br & _L & Campnosperma brevipetiolatum Volkens \\
\hline 10 & Camp_br & _- & Campnosperma brevipetiolatum Volkens \\
\hline 11 & Cana_hi & L & Canarium hirsutum Willd. \\
\hline 12 & Cana_hi & _S & Canarium hirsutum Willd. \\
\hline 13 & Cana_in & _L & Canarium indicum $\mathrm{L}$. \\
\hline 14 & Cana_in & _S & Canarium indicum $\mathrm{L}$. \\
\hline 15 & Cara_br & $\_$L & Carallia brachiata (Lour.) Merr. \\
\hline 16 & Cara_br & S & Carallia brachiata (Lour.) Merr. \\
\hline 17 & Clei_pa & _L & Cleistanthus papuanus (Lauterb.) Jabl. \\
\hline 18 & Clei_pa & _S & Cleistanthus papuanus (Lauterb.) Jabl. \\
\hline 19 & Cory_la & _L & Corynocarpus laevigatus J.R.Forst. \& G.Forst. \\
\hline 20 & Cory_la & _S & Corynocarpus laevigatus J.R.Forst. \& G.Forst. \\
\hline 21 & Cryp_pa & L & Cryptocarya palmerensis C.K.Allen \\
\hline 22 & Cryp_pa & _S & Cryptocarya palmerensis C.K.Allen \\
\hline 23 & Cryp_sp & _L & Cryptocarya $\mathrm{sp}$ \\
\hline 24 & Cryp_sp & $\_\mathrm{S}$ & Cryptocarya $\mathrm{sp}$ \\
\hline 25 & Deca_pa & $\_$L & Decaspermum parviflorum (Lam.) A.J.Scott \\
\hline 26 & Deca_pa & S & Decaspermum parviflorum (Lam.) A.J.Scott \\
\hline 27 & Dill_pa & _L & Dillenia papuana Martelli \\
\hline 28 & Dill_pa & _S & Dillenia papuana Martelli \\
\hline 29 & Dios_pi & $\_$L & Diospyros pilosanthera Blanco \\
\hline 30 & Dios_pi & S & Diospyros pilosanthera Blanco \\
\hline 31 & Drac_da & _L & Dracontomelon dao (Blanco) Merr. \& Rolfe \\
\hline 32 & Drac_da & _S & Dracontomelon dao (Blanco) Merr. \& Rolfe \\
\hline 33 & Dryp_gl & $\_$L & Drypetes globosa (Merr.) Pax \& K.Hoffm. \\
\hline 34 & Dryp_gl & _S & Drypetes globosa (Merr.) Pax \& K.Hoffm. \\
\hline 35 & Dyso_mo & $\_$L & Dysoxylum mollissimum Blume \\
\hline 36 & Dyso_mo & _S & Dysoxylum mollissimum Blume \\
\hline 37 & Elae_an & _L & Elaeocarpus angustifolius Blume \\
\hline 38 & Elae_an & _S & Elaeocarpus angustifolius Blume \\
\hline 39 & Endi_ru & L & Endiandra rubescens (Blume) Miq. \\
\hline 40 & Endi_ru & _S & Endiandra rubescens (Blume) Miq. \\
\hline 41 & Endo_me & _L & Endospermum medullosum L.S.Sm. \\
\hline 42 & Endo_me & _- & Endospermum medullosum L.S.Sm. \\
\hline 43 & Flin_pi & $\_$L & Flindersia pimenteliana F.Muell. \\
\hline 44 & Flin_pi & _S & Flindersia pimenteliana F.Muell. \\
\hline 45 & Galb_be & $\_$L & Galbulimima belgraveana (F.Muell.) Sprague \\
\hline 46 & Galb_be & _S & Galbulimima belgraveana (F.Muell.) Sprague \\
\hline 47 & Garc_la & _L & Garcinia latissima Miq. \\
\hline 48 & Garc_la & _S & Garcinia latissima Miq. \\
\hline 49 & Giro_ne & _L & Gironniera nervosa Planch. \\
\hline 50 & Giro_ne & _S & Gironniera nervosa Planch. \\
\hline 51 & Gmèl_se & _L & Gmelina sessilis C.T.White \& W.D.Francis ex Lane-Poole \\
\hline 52 & Gmel_se & _S & Gmelina sessilis C.T.White \& W.D.Francis ex Lane-Poole \\
\hline 53 & Gnet_gn & $\_$L & Gnetum gnemon L. \\
\hline 54 & Gnet_gn & _S & Gnetum gnemon $\mathrm{L}$. \\
\hline 55 & Gono_li & _L & Gonocaryum littorale (Blume) Sleumer \\
\hline 56 & Gono_li & _S & Gonocaryum littorale (Blume) Sleumer \\
\hline 57 & Gymn_fa & $\_$L & Gymnacranthera farquhariana (Hook.f. \& Thomson) Warb. \\
\hline 58 & Gymn_fa & S & Gymnacranthera farquhariana (Hook.f. \& Thomson) Warb. \\
\hline 59 & Hapl_fl & _L & Haplolobus floribundus (K.Schum.) H.J.Lam \\
\hline 60 & Hapl_fl & _S & Haplolobus floribundus (K.Schum.) H.J.Lam \\
\hline 61 & Heri_sy & $\_$L & Heritiera sylvatica $\mathrm{S}$. Vidal \\
\hline 62 & Heri_sy & _- & Heritiera sylvatica S.Vidal \\
\hline 63 & Homa_fo & _L & Homalium foetidum Benth. \\
\hline 64 & Homa_fo & _S & Homalium foetidum Benth. \\
\hline 65 & Hope_ce & _L & Hopea celtidifolia Kosterm. \\
\hline 66 & Hope_ce & S & Hopea celtidifolia Kosterm. \\
\hline 67 & Hope_no & _L & Hopea novoguineensis Slooten \\
\hline
\end{tabular}




\begin{tabular}{|c|c|c|c|}
\hline 68 & Hope_no & S & Hopea novoguineensis Slooten \\
\hline 69 & Hope_pa & L & Hopea papuana Diels \\
\hline 70 & Hope_pa & - $\mathrm{S}$ & Hopea papuana Diels \\
\hline 71 & Hors_la & - $\mathrm{L}$ & Horsfieldia laevigata Warb. \\
\hline 72 & Hors_la & - $\mathrm{S}$ & Horsfieldia laevigata Warb. \\
\hline 73 & Ints_pa & _L & Intsia palembanica Miq. \\
\hline 74 & Ints_pa & S & Intsia palembanica Miq. \\
\hline 75 & Knem_in & _L & Knema intermedia Warb. \\
\hline 76 & Knem_in & $-\mathrm{S}$ & Knema intermedia Warb. \\
\hline 77 & Lith_ru & _L & Lithocarpus rufovillosus (Markgr.) Rehder \\
\hline 78 & Lith_ru & -S & Lithocarpus rufovillosus (Markgr.) Rehder \\
\hline 79 & Lits_ti & _L & Litsea timoriana Span. \\
\hline 80 & Lits_ti & -S & Litsea timoriana Span. \\
\hline 81 & Mani_br & _L & Maniltoa browneoides Harms \\
\hline 82 & Mani_br & _S & Maniltoa browneoides Harms \\
\hline 83 & Medu_la & _L & Medusanthera laxiflora (Miers) R.A.Howard \\
\hline 84 & Medu_la & $-\mathrm{S}$ & Medusanthera laxiflora (Miers) R.A.Howard \\
\hline 85 & Meli_el & L & Melicope elleryana (F. Muell.) T.G. Hartley \\
\hline 86 & Meli_el & - $\mathrm{S}$ & Melicope elleryana (F. Muell.) T.G. Hartley \\
\hline 87 & Myri_fa & L & Myristica fatua Houtt. \\
\hline 88 & Myri_fa & - $\mathrm{S}$ & Myristica fatua Houtt. \\
\hline 89 & Pala_lo & _L & Palaquium lobbianum Burck \\
\hline 90 & Pala_lo & $-\mathrm{S}$ & Palaquium lobbianum Burck \\
\hline 91 & Para_pr & L & Pararchidendron pruinosum (Benth.) I.C.Nielsen \\
\hline 92 & Para_pr & _S & Pararchidendron pruinosum (Benth.) I.C.Nielsen \\
\hline 93 & Para_ve & - $\mathrm{L}$ & Parastemon versteeghii Merr. \& L.M.Perry \\
\hline 94 & Para_ve & $-\mathrm{S}$ & Parastemon versteeghii Merr. \& L.M.Perry \\
\hline 95 & Pime_am & _L & Pimelodendron amboinicum Hassk. \\
\hline 96 & Pime_am & - $\mathrm{S}$ & Pimelodendron amboinicum Hassk. \\
\hline 97 & Plan_ke & L & Planchonella keyensis H.J.Lam \\
\hline 98 & Plan_ke & - $\mathrm{S}$ & Planchonella keyensis H.J.Lam \\
\hline 99 & Pome_ac & _L & Pometia acuminata Radlk. \\
\hline 100 & Pome_ac & - S & Pometia acuminata Radlk. \\
\hline 101 & Pome_pi & _L & Pometia pinnata J.R.Forst. \& G.Forst. \\
\hline 102 & Pome_pi & S & Pometia pinnata J.R.Forst. \& G.Forst. \\
\hline 103 & Prun_ar & L & Prunus arborea (Blume) Kalkman \\
\hline 104 & Prun_ar & $-\mathrm{S}$ & Prunus arborea (Blume) Kalkman \\
\hline 105 & Prun_ja & _L & Prunus javanica (Teijsm. \& Binn.) Miq. \\
\hline 106 & Prun_ja & -S & Prunus javanica (Teijsm. \& Binn.) Miq. \\
\hline 107 & Rhod_ci & _L & Rhodamnia cinerea Jack \\
\hline 108 & Rhod_ci & $-\mathrm{S}$ & Rhodamnia cinerea Jack \\
\hline 109 & Siph_ce & L & Siphonodon celastrineus Griff. \\
\hline 110 & Siph_ce & - $S$ & Siphonodon celastrineus Griff. \\
\hline 111 & Siph_sp & L & Siphonodon sp \\
\hline 112 & Siph_sp & -S & Siphonodon $\mathrm{sp}$ \\
\hline 113 & Sloa_pu & _L & Sloanea pullei O.C.Schmidt ex A.C.Sm. \\
\hline 114 & Sloa_pu & S & Sloanea pullei O.C.Schmidt ex A.C.Sm. \\
\hline 115 & Ster_sh & - $\mathrm{L}$ & Sterculia shillinglawii F.Muell. \\
\hline 116 & Ster_sh & $-\mathrm{S}$ & Sterculia shillinglawii F.Muell. \\
\hline 117 & Syzy_sp1 & _L & Syzygium sp1 \\
\hline 118 & Syzy_sp1 & - $\mathrm{S}$ & Syzygium $\mathrm{sp} 1$ \\
\hline 119 & Teij_bo & L & Teijsmanniodendron bogoriense Koord. \\
\hline 120 & Teij_bo & S & Teijsmanniodendron bogoriense Koord. \\
\hline 121 & Term_co & L & Terminalia copelandi Elmer \\
\hline 122 & Term_co & $-\bar{S}$ & Terminalia copelandi Elmer \\
\hline 123 & Timo_ca & L & Timonius carii S.P.Darwin \\
\hline 124 & Timo_ca & - $\mathrm{S}$ & Timonius carii S.P.Darwin \\
\hline 125 & Tris_ma & _L & Tristaniopsis macrosperma (F.Muell.) Peter G.Wilson \& J.T.Waterh. \\
\hline 126 & Tris_ma & S & Tristaniopsis macrosperma (F.Muell.) Peter G.Wilson \& J.T.Waterh. \\
\hline 127 & Vati_ra & - $\mathrm{L}$ & Vatica rassak Blume \\
\hline 128 & Vati_ra & $-\mathrm{S}$ & Vatica rassak Blume \\
\hline 129 & Xant_pa & _L & Xanthophyllum papuanum Whitmore ex Meijden \\
\hline 130 & Xant_pa & S & Xanthophyllum papuanum Whitmore ex Meijden \\
\hline 131 & Xant_no & _L & Xanthostemon novaguineensis Valeton \\
\hline 132 & Xant_no & $\mathrm{S}$ & Xanthostemon novaguineensis Valeton \\
\hline
\end{tabular}

